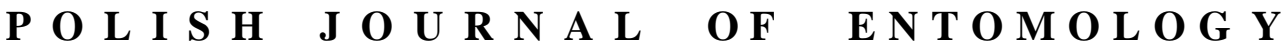

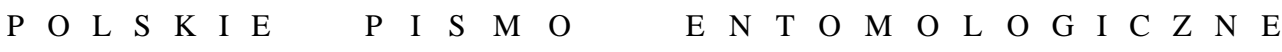

VOL. 84: $145-154$

Lublin

30 September 2015

DOI: $10.1515 /$ pjen-2015-0012

\section{Notes on Neotropical Microcorsini and Enarmoniini (Lepidoptera: Tortricidae)}

\author{
JÓZEF RAZOWSKI ${ }^{1}$, VITOR O. BECKER ${ }^{2}$ \\ ${ }^{1}$ Institute of Systematic and Experimental Zoology, Polish Academy of Sciences, Kraków, \\ 31-016 Sławkowska 17, Poland, e-mail: Razowski@isez.pan.krakow.pl \\ ${ }^{2}$ Reserve Serra Bonita PO Box 01, 45880 Camacan BA, Brazil, \\ e-mail: Becker.vitor@gmail.com
}

\begin{abstract}
One genus - Auchenancylis gen. $\mathrm{n}$. - and the following species are described as new: Cryptaspasma sanvito sp. n., Pseudancylis sphensaccula sp. n., Aglaopollex niveofascia sp. n., Aglaopollex gana sp. n., Auchenancylis macrauchenia sp. n. Hemimene sevocata is transferred to Auchancylis.
\end{abstract}

KEY WORDS: Lepidoptera, Tortricidae, Microcorsini, Enarmoniini, Neotropical, new taxa.

\section{INTRODUCTION}

The Neotropical olethreutine tribes Microcorsini and Enarmoniini are little known. The Microcorsini are represented by six species of Cryptaspasma, described chiefly from Brazil. We have practically no data on their distribution except for the type localities. One species $(C$. anaphorana WALSINGHAM, 1914) and another described below are known from Central America, Panama and Costa Rica, which are the most northerly known localities of the genus.

Enarmoniini have a world-wide distribution with an Oriental-Australian centre. In the New World there occur Ancylis HÜBNER, 1825 (35 Nearctic and 8 Neotropical species), Hystrichophora WALSINGHAM, 1879 (11 Nearctic species), Eucosmomorpha OBRAZTSOV, 1951 (one Nearctic species), Aglaopollex RAZOWSKI \& PELZ, 2011 (Neotropical, 9 species) and the monotypical, Neotropical Auchenancylis gen. n. 


\section{Acknowledgements}

The authors thank Artur CZEKAJ, Witold ZAJDA and Łukasz PRZYBYŁOWICZ, Kraków, for taking the photographs and arranging the plates.

\section{MATERIAL}

All the specimens were collected by the junior author in Brazil, Ecuador and Costa Rica. The types of the newly described species have been temporarily deposited in the Becker Collection, Camacan, Brazil and will eventually be housed in one of the Brazilian museums. Some specimens have been kindly donated to the Institute of Systematics and Evolution of Animals, PAS, Kraków.

Note. The numbers cited on the labels of the type material are the entry numbers of the specimens in the register book of the above-mentioned collection.

Abbreviations used: GS - genitalia slide, WZ - Witold ZAJDA.

\section{RESULTS}

Microcorsini

\section{Cryptaspasma WALSINGHAM, 1900}

Cryptaspasma Walsingham, 1900, Ann. Mag. Nat. Hist.(5): 462; type-species: Notocelia helota MEYRICK, 1905, Oriental (Sri Lanka).

Cryptaspasma has a worldwide distribution; six species have been described from the Neotropical region. DIAKONOFF (1959) revised the genus and illustrated its species, and HORAK (2006) redescribed the genus and discussed its subgenera.

\section{Cryptaspasma sanvito sp. $\mathbf{n}$.}

(Figs 1, 6)

\section{Diagnosis}

C. sanvito is closely related to C. anaphorana (WALSINGHAM, 1914) from Panama, but sanvito is distinct by its sharp ventrocaudal projection from the angle of the sacculus and the strong, setose process from before the base of the cucullus. 


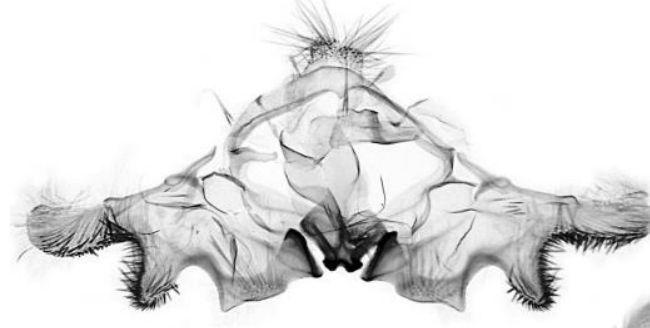

1
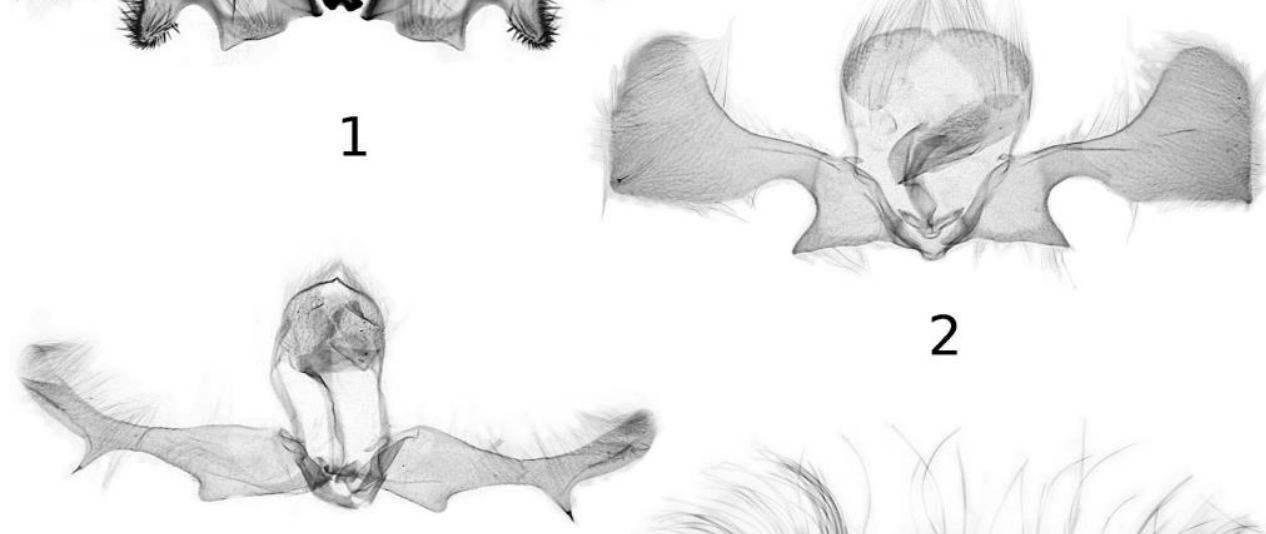

2

3

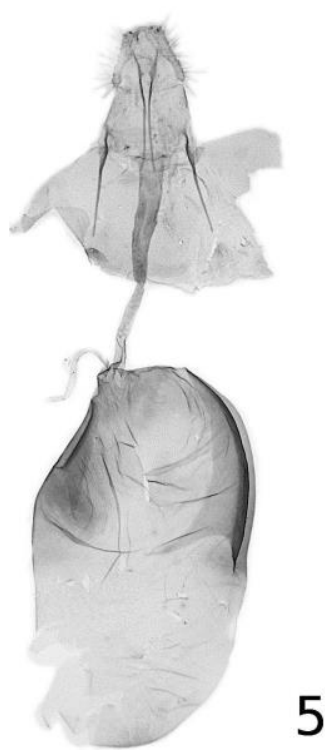

5

\section{4}

Figs 1-5. Male and female genitalia. 1 - Cryptaspasma sanvito sp. n., holotype; 2 - Pseudancylis sphensaccula sp. n., holotype; 3 - Aglaopollex niveofascia sp. n., holotype; 4 -A. gana sp. n., holotype; 5 - Auchenancylis macrauchenia sp. n., holotype. 


\section{Description}

Wing span $15 \mathrm{~mm}$. Head and thorax pale brown. Forewing not expanding terminad; costa gradually curved outwards; termen short, slightly convex. Wing brown with rusty hue, paler at apex. Cilia brownish. Hindwing brownish with paler cilia.

Male genitalia (Fig. 1). Socii broad, fused basally; inner processes of basal part of pedunculi long; valva broad basally; sacculus slightly convex with ventrocaudal termination; strong processes from before cucullus with dense spines extending continuously along cucullus; cucullus slender; aedeagus slender, sclerotized before long ventral termination.

Female unknown.

\section{Material}

Holotype male: "Costa Rica: S.[an] Vito 1100 m, 24-25. XI. 1973, V.O BECKER Col; Col. BECKER 38535"; GS $621 \mathrm{WZ}$.

\section{Enarmoniini}

\section{Pseudancylis HORAK, 2006}

Pseudancylis HORAK, 2006, CSIRO Publishing: 282; type-species: Ancylis acrogypsa TURNER, 1916, Australian.

Pseudancylis was described for a single Australian species but HORAK (2006) transferred the Oriental Ancylis rostrifera (MEYRICK, 1912) to this genus and RAZOWSKI (in press) found two new species in Fiji.

\section{Pseudancylis sphensaccula sp. $\mathbf{n}$.}

(Figs 2, 7)

\section{Diagnosis}

P. sphensaccula is related to the Australian P. acrogypsa (TURNER, 1916) and the Oriental A. rostrifera (MEYRICK, 1912), but $P$. sphensaccula has no uncus, the valva has a short neck and the terminal part of the sacculus is wedge-shaped.

\section{Description}

Wing span $14 \mathrm{~mm}$. Head and collar greyish brown, remaining part of thorax and labial palpus whitish. Forewing uniformly broad throughout; costa slightly bent to middle; apex elongate; termen slightly sinuate. Ground colour cream white dotted and sparsely strigulated brownish; costal strigulae whitish, divisions brown; apical third of wing suffused orange. Markings brown: basal blotch consisting of brown strigulae; median fascia in form of brown 

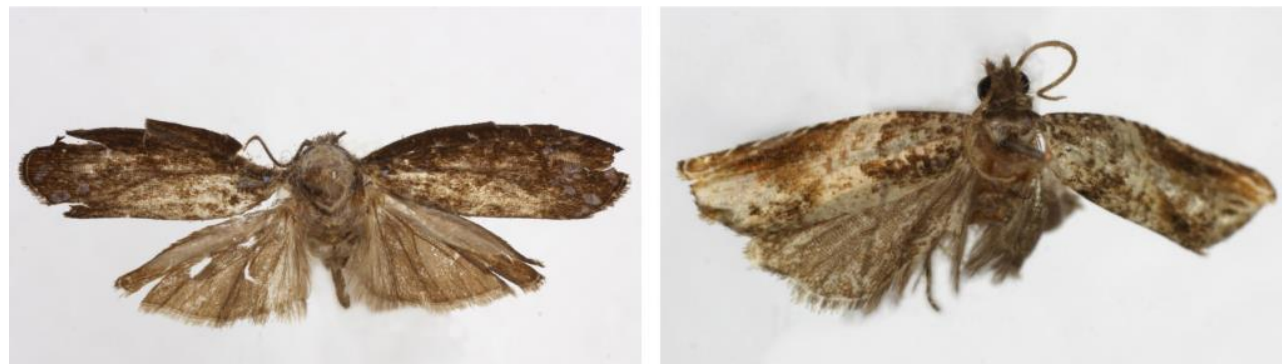

6 7
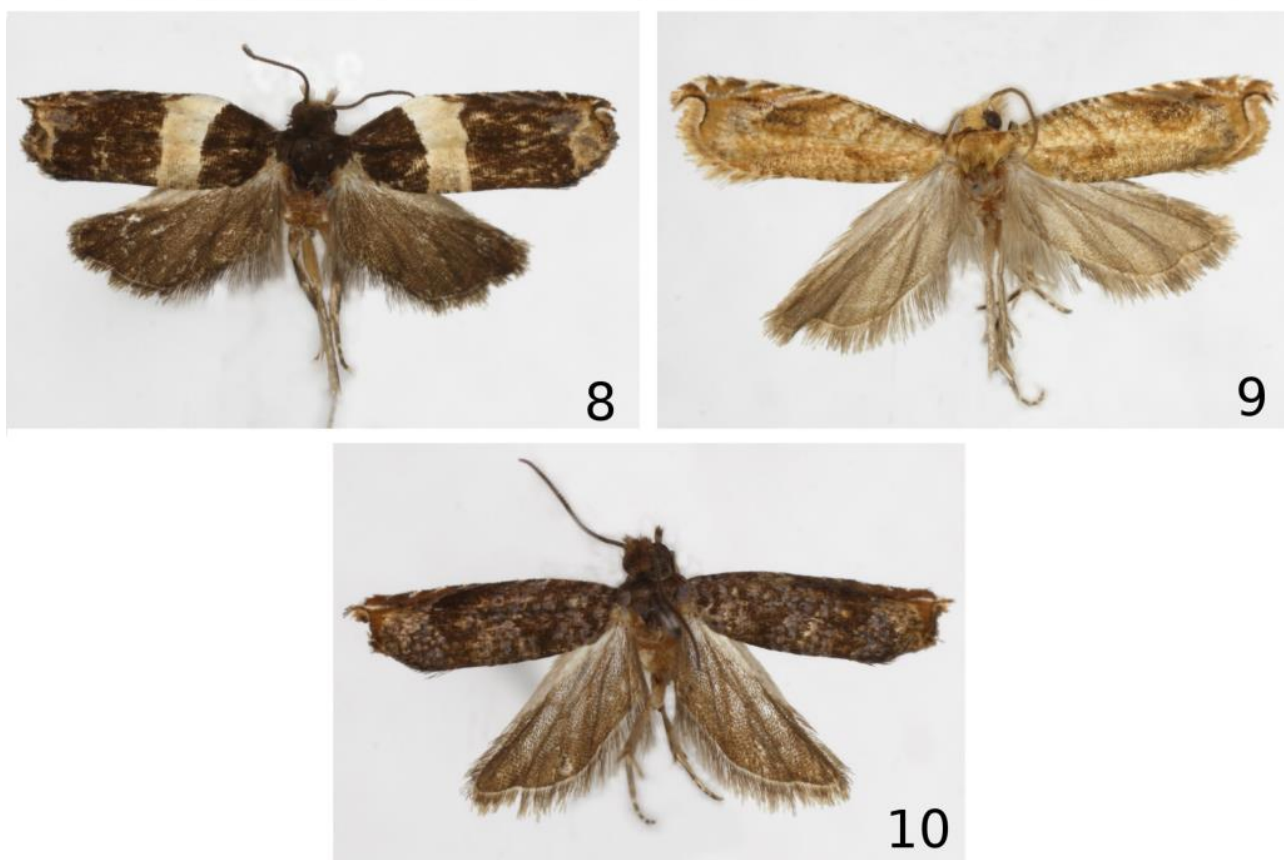

Figs 6-10. Adults: 6 - Cryptaspasma sanvito sp. n., holotype; 7 - Pseudancylis sphensaccula sp. n., holotype; 8 - Aglaopollex niveofascia sp. n., holotype; 9 - A. gana sp. n., holotype; 10 - Auchenancylis macrauchenia sp. n., holotype.

mixed with orange costal part and brownish dorsal part. Cilia worn. Hindwing brownish; cilia paler.

Male genitalia (Fig. 2). Uncus absent; socii very large, broad proximally, tapering dorsomedially; basal part of valva broad, short, sacculus straight ventrally with large wedgeshaped distal process; neck of valva short, ventral incision deep; cucullus large, expanding posterad, rather straight caudally, with minute pollex; aedeagus broad, longer than sacculus; 
cornuti present.

Female unknown.

\section{Material}

Holotype male: "Brasil: M[inas]G[erais], Caraca 1300 m, 2-4. I. 1985, V.O. BECKER Col; Col. BECKER 54359”, GS 810 WZ.

\section{Etymology}

The specific name refers to the shape of the end of the sacculus; Greek: sphen - a wedge.

\section{Aglaopollex RAzoWSKi \& Pelz, 2011}

Aglaopollex RAZOWSKI \& PELZ, 2011, SHILAP Revta Lepid., 39(153): 40; type-species: Aglaopollex storthynx RAZOWSKI \& PELZ, 2011, Ecuador.

Aglaopollex is closely related to Aglaogonia HORAK, 2006, known to date from Australia. Aglaopollex differs from Aglaogonia chiefly in the shape of the signum, which in Aglaopollex is blade-shaped like that in Ancylis HÜBNER, 1825; in Aglaogonia there is a scobinate concavity.

\section{Distribution}

The genus was known only from Ecuador. Now one Brazilian species has been discovered.

\section{Aglaopollex niveofascia sp. $\mathbf{n}$.}

(Figs 3, 8)

\section{Diagnosis}

A. niveofascia is closely related to A. onepsia RAZOWSKI \& PELZ, 2011 but A. niveofascia has a complete, broad snow-white fascia at $1 / 4$ length of the forewing, while the remainder of the wing surface is black; the valva has a long ventral incision and there is a very long caulis. The genus consists of seven Ecuadoran species.

\section{Description}

Wing span $10 \mathrm{~mm}$. Head and thorax black, frons and labial palpus snow-white. Forewing uniformly broad throughout; costa bent at 1/3 then straight; apex and termen typical of the genus. Ground colour white in form of postbasal fascia; costal strigulae fine, white; terminal part brownish cream; remaining wing area black with diffuse, rusty shades. Cilia brownish cream, blackish at tornus. Hindwing brown; cilia paler. 
Male genitalia (Fig. 3). Apex of tegumen with minute, sharp projection; socius very large; valva broad basally; sacculus straight ventrally, rounded ventrocaudally; ventral incision of valva long; neck slender, tapering towards a finger-like process terminating in a spine; cucullus slender, somewhat shorter than cucullus; aedeagus moderate; caulis very long.

Female unknown.

\section{Material}

Holotype male: "Ecuador: Napo, Misahualli, XII. 1992, V.O. BECKER Col; Col. BECKER 102211"; GS 1293 WZ. Paratype an identically labelled male.

\section{Etymology}

The name refers to the colouration of the forewing fascia: Latin: niveus - white.

\section{Aglaopollex gana sp. n.}

(Figs 4, 9)

\section{Diagnosis}

A. gana is related to A. onepsia RAzOWSKI \& PELZ, 2011 but in A. gana the sacculus has a broadly rounded angulation, the valva has a shallow ventral incision, there is a short cucullus, and the forewing is ferruginous cream in colour.

\section{Description}

Wing span $14 \mathrm{~mm}$. Head pale ferruginous cream, labial palpus cream; thorax darker than head. Forewing weakly expanding posteriorly; costa slightly, uniformly convex; apex and termen typical of the genus. Ground colour cream tinged and indistinctly strigulated, with some parallel transverse pale ferruginous lines; costal strigulae white; costal and dorsal interruptions brown-yellow, termen similarly edged. Markings darker than strigulation: postbasal line convex; median fascia extending from costa to middle of wing. Cilia brownish yellow with black basal line from apex to M3. Hindwing pale brownish, cilia lighter.

Variation. Paratype (GS $864 \mathrm{WZ}$ ) ground colour creamier; transverse lines distinct.

Male genitalia (Fig. 4). Terminal part of tegumen broadly rounded; socius broad, subtriangular posteriorly; basal part of valva fairly broad; sacculus weakly angulate; neck of valva broad; pollex distinct; cucullus large, oval; aedeagus fairly broad.

Female unknown.

\section{Material}

Holotype male: "Brasil: R[io de]J[aneiro], P[ar]q Nat.[ional] Itatiaya, 2400 m, 18. X. 1985, V.O. BECKER Col; Col. BECKER 66382”, GS 864 WZ; Paratypes 6 males labelled as above or 
dated 19. X. 1985, Col. Nr 66518, one with GS 866 WZ.

\section{Etymology}

The name refers to the nice facies of the moth: Greek: gana - an adornment.

\section{Auchenancylis gen. $\mathbf{n}$.}

Type-species: Auchenancylis macrauchenia sp. n.

\section{Diagnosis}

Auchenancylis is related to Aglaopollex RAZOWSKI \& PELZ, 2011 as the shapes of the wings venation, valva and aedeagus show. Auchenancylis is distinguished chiefly by the shape of the top part of the tegumen, the neck of the valva, the reduced cucullus, and the lack of an uncus and scent organs connected with the pedunculus.

\section{Description}

Forewing similar in shape and venation to that in Ancylis and Aglaopollex.

Male genitalia. Tegumen not extending apically; pedunculi slender; gnathos ill-defined; vinculum broad; valva broad basally; neck very slender, arched; pollex large; cucullus rudimentary; aedeagus broad, convex ventroposteriorly; cornuti not found.

Female unknown.

\section{Distribution and biology}

Two species included; the type-species is Brazilian, sevocata was described from British Guiana. The moths were taken in December, February and April, the latter at an altitude of 850 m.

\section{Etymology}

The name consists of the generic name Ancylis and part of the specific name of the type species (Greek: auchen - a neck).

\section{Auchenancylis macrauchenia sp. $\mathbf{n}$.}

(Figs 5, 10)

\section{Diagnosis}

A. macrauchenia is closely related to A. sevocata (MEYRICK, 1916) but A. macrauchenia has a dark forewing, a long pollex and the neck of the valva is less strongly arched. The facies is similar to that in several Enarmoniini (see diagnosis of the genus); facies as in Aglaogonia 
HorAK, 2006, Aglaopteryx, e.g. A. onepsia RAZOWSKI \& PELZ, 2014 from Ecuador but A. onepsia has distinct, white postbasal forewing interfascia.

\section{Description}

Wing span $10 \mathrm{~mm}$. Head brown, basal 3/4 of labial palpus paler, vertex rusty; thorax brown, end of tegula creamier. Forewing uniformly broad throughout; costa straight from beyond basal third; apex sickle-shaped; termen sinuate. Ground colour brownish dotted refractive silver-grey, rusty along costa, near tornus and in terminal area; costal strigulae white; divisions rusty and brown. Markings brown with weak rusty admixture: basal blotch well visible at dorsum, median fascia distinctly convex. Cilia (damaged) rusty brown. Hindwing brownish; cilia paler.

Male genitalia (Fig. 5) as described for the genus.

\section{Material}

Holotype male: "Brasil: M[inas]G[erais], Nova Lima 850 m, 30. XII. 1968, V.O. BECKER Col; Col. BECKER 60563"; GS $890 \mathrm{WZ}$; paratypes 10 males labelled as above or dated 1-3. IV. 1983, Nr 50781, one with GS 888 WZ.

\section{Auchenancylis sevocata (MEYRICK, 1916), comb. n.}

Hemimene sevocata MEYRICK, 1916, Exotic Microlep. 2: 29, type locality: Bartica, British Guiana. ClARKE, 1958, MEYRICK types of Microlep. 3: 419, pl. 208, fig. 2, 2a.

\section{Diagnosis}

A. sevocata is closely related to A. macrauchenia but sevocata is smaller (wing span 8 $\mathrm{mm}$ ), has a pale coloured posterior third of forewing and a strongly reduced pollex.

\section{REFERENCES}

DiAKONOFF A. 1959. Revision of Cryptaspasma WALSINGHAM, 1900 (Lepidoptera, Tortricidae). Zoologische Verhandelingen 43: 1-60, 3 pls.

HORAK M. 2006. Monographs on Australian Lepidoptera Series 10. Olethreutine moths of Australia (Lepidoptera: Tortricidae). CSIRO, Canberra.

RAZOWSKI J. in press. Tortricidae (Lepidoptera) from Fiji Islands. 
Razowski J., Pelz V. 2011. Ecuadoran species of Aglaopollex Razowski \& Pelz, gen. n., Ancylis HÜBNER, [1825] and Rhopobota LEDERER, 1859 (Lepidoptera: Tortricidae). SHILAP Revista de Lepidopterologia 39(153): 39-59.

Received: 1 June 2015

Accepted: 2 July 2015 